\title{
SHARIA BANKS' PERFORMANCE IN INDONESIA : A PANEL MODEL APPROACH
}

\author{
Nurismalatri ${ }^{1)}$ \\ 1) dosen universitas pamulang, email : nurismalatri86@gmail.com
}

\section{ARTICLES \\ INFORMATION \\ JURNAL SEKURITAS \\ (Saham, Ekonomi, Keuangan dan Investasi ) \\ Vol.2, No.2, Januari 2019 \\ Halaman : $131-140$ \\ C LPPM \& Prodi Manajemen \\ UNVERSITAS PAMULANG \\ ISSN (online) : 2581-2777 \\ ISSN (print) : :2581-2696}

Keyword:

Sharia Bank, ROA, CAR, NPF, FDR, and BOPO

JEL. classification :

C33, G21, G34, N25

\section{Contact Author :}

PRODI MANAJEMEN UNPAM

JL.Surya Kencana No.1 Pamulang

Tangerang Selatan - Banten

Telp. (021) 7412566, Fax (021) 7412491 Email :

jurnalfinance.unpam@gmail.com
Kesuksesan sebuah lembaga keuangan bank dapat dipengaruhi oleh banyak faktor, pada penelitian ini ditinjau berdasarkan kinerja keuangan yaitu rasio keuangan. Penelitian ini memiliki tujuan menganalisis faktor faktor yang mempengaruhi ROA perbankan syariah di Indonesia. Analisis data yang digunakan adalah regresi data panel dimana CAR, NPF, BOPO dan FDR sebagai variabel bebas sedangkan ROA sebagai variabel terikat. Sampel yang digunakan yaitu 11 bank Umum Syariah dengan periode data tahun 2010 - 2017. Semua tahap pengolahan data penelitian ini menggunakan alat perangkat lunak Stata 10. Hasil penelitian ini diperoleh hasil bahwa nilai NPF dan BOPO berpengaruh negatif terhadap ratio ROA.

The success rate of a financial institution can be influenced by many factors. This level of success can be seen based on its financial performance which is represented by financial ratio analysis. This research examines the Profitability of BUS by Using Panel Regression Model with CAR, NPF, FDR, and BOPO as independent variables, where ROA is dependent variable.

The data used in in this research was obtained from the annual financial report sharia banking period 2010 to 2017. After going throught the purposive sample, then the sample is feasible to use as many as 11 of BUS.

The results shows that the variables CAR and FDR were not significantly influenced ROA. Variables NPF and BOPO were significantly negative influenced ROA. From these two variables have significant effect, NPF variable that have the most impact on ROA 


\section{A. Pendahuluan}

Lembaga keuangan perbankan syariah di Indonesia sudah hadir dalam kurun waktu 26 tahun semenjak berdirinya bank Muamalat Indonesia pada tahun 1992, yang kemudian pemerintah memberlakukan UU No.10 tahun 1998 yang memberi peluang bagi Bank Umum untuk melayani transaksi syariah (dual banking system) sebagai tindak lanjut dari pemikiran Pengembangan Sistem Ekonomi Syariah. Hal ini disambut dengan respon yang sangat baik dan cepat oleh bank bank konvensional dengan membentuk bank umum syariah atau unit usaha syariah.

Pada perkembangannya, sudah banyak sekali kegiatan usaha yang dilakukan oleh bank syariah diantaranya yaitu Menghimpun dana dalam bentuk simpanan berupa Giro, Tabungan, atau bentuk lainnya atau dalam bentuk investasi berupa Deposito, Bank syariah juga menyalurkan pembiayaan bagi hasil berdasarkan Akad mudharabah, Akad musyarakah, atau Akad lain yang tidak bertentangan dengan Prinsip Syariah seperti Akad murabahah, Akad salam, Akad istishna atau Akad qardh.

Kegiatan lainnya yang terkait dengan pengambil alihan hutang berdasarkan Akad hawalah, melakukan usaha kartu debit dan/atau kartu pembiayaan. Bank syariah juga membeli surat berharga yang diterbitkan oleh pemerintah dan/atau Bank Indonesia, Melakukan penitipan untuk kepentingan pihak lain, Menyediakan tempat untuk menyimpan barang dan surat berharga, memberikan fasilitas letter of credit atau Bank garansi serta melakukan kegiatan lain yang lazim dilakukan di bidang perbankan dan di bidang sosial sepanjang tidak bertentangan dengan Prinsip Syariah dan sesuai dengan ketentuan perundang- undangan; seperti kegiatan valuta asing atau penyertaan modal pada Bank Umum Syariah atau lembaga keuangan.

Banyaknya kegiatan usaha bank syariah di atas, dikemas menjadi produk produk yang menarik dan kompetitif, hal ini menunjukkan bahwa Bank Syariah sudah sukses mengembangkan produk yang sesuai dengan kebutuhan konsumen dan menjadi pilihan utama. Kesuksesan Bank syariah juga dapat diukur dalam bentuk kinerja. Salah satu cara untuk mengukur kinerja adalah tingkat keuntungan. Bank dengan keuntungan yang optimal dengan kata lain tingkat profitabilitasnya meningkat, maka dapat melakukan banyak hal lainnya seperti meningkatkan laba ditahan, peningkatan pelayanan kepada nasabah dengan melalui peningkatan skill para pegawainya maupun peningkatan kualitas dan kuantitas sarana dan prasarananya.

Faktor lainnya yang dapat dilihat dari kesuksesan Bank Syariah adalah dari perkembangan kantor Bank Syariah sudah semakin banyak dari waktu ke waktu, dimana per bulan Juni tahun 2018, kantor bank syariah sudah mencapai 2757 dengan total 12 BUS dan UUS sebanyak 22.

Tabel 1.1

Perkembangan Kelembagaan dan Kinerja Perbankan Syariah Indonesia

\begin{tabular}{rrrrrrrrr}
\hline Indikator & 2010 & 2011 & 2012 & 2013 & 2014 & 2015 & 2016 & 2017 \\
\hline BUS & 11 & 11 & 11 & 11 & 12 & 12 & 13 & 13 \\
UUS & 23 & 24 & 24 & 23 & 22 & 22 & 21 & 21 \\
Jumlah kantor & 1.477 & 1.737 & 2.264 & 2.588 & 2.483 & 2.301 & 2.201 & 2.728 \\
\hline ASET (miliar & & & & & & & & \\
Rp) & 97.519 & 145.467 & 195.018 & 242.276 & 272.343 & 296.262 & 356.504 & 424.181 \\
DPK (miliar & & & & & & & & \\
Rp) & 76.036 & 115.415 & 147.512 & 183.534 & 217.858 & 231.175 & 279.335 & 334.719 \\
PYD (miliar & & & & & & & & \\
Rp) & 68.181 & 102.655 & 147.505 & 184.122 & 199.330 & 212.996 & 248.007 & 285,695 \\
\hline
\end{tabular}


Faktor lainnya yang dapat dilihat dari kesuksesan Bank Syariah dilihat dari perkembangan kantor Bank Syariah sudah semakin banyak dari waktu ke waktu. Berdasarkan data tabel diatas, diketahui jumlah Bank Umum Syariah pada tahun 2010 sebanyak 11 Bank terdiri dari 1.477 kantor, berkembang menjadi 12 Bank dan 2.483 kantor pada tahun 2014, pada tahun 2017 menjadi 13 Bank dan 2.728 kantor. Sampai dengan bulan Juni 2018, industri perbankan syariah telah mempunyai jaringan sebanyak 13 Bank Umum Syariah (BUS), 21 Unit Usaha Syariah (UUS), dengan total jaringan kantor mencapai 2.757 kantor yang tersebar di hampir seluruh penjuru nusantara.

Total aset perbankan syariah tahun 2017 mencapai Rp149,3 triliun (BUS \& UUS Rp424,2 triliun atau tumbuh sebesar $18,9 \%$ (yoy) dari posisi tahun sebelumnya. Industri perbankan syariah mampu menunjukkan akselerasi pertumbuhan yang tinggi dengan rata-rata sebesar 16,95\% pertahun dalam lima tahun terakhir (2013-2017), sementara rata-rata pertumbuhan perbankan nasional hanya sebesar $11,75 \%$ pertahun. Pertumbuhan perbankan syariah jauh lebih tinggi dari pertumbuhan perbankan nasional dan berhasil meningkatkan porsi perbankan syariah dalam perbankan nasional menjadi 4,0\%.

Namun apabila dihitung dengan usia kemunculan semenjak 1992 hingga saat ini sudah 26 tahun, kinerja bank syariah masih jauh di bawah kinerja bank konvensional. Hal ini menjadi pertanyaan lanjutan mengenai bagaimanakah tingkat kesuksesan perbankan syariah di Indonesia. Apakah mungkin operasional bank syariah BUS sudah efisien. Maka muncul pertanyaan penelitian yang akan dijawab dalam penelitian ini yaitu bagaimana kesuskesan Bank Syariah di Indonesia yang dilihat dari rasio profitabilitas BUS selama periode 2010-2017.

\section{B. Perumusan Masalah}

Berdasarkan identifikasi dan pembatasan masalah diatas, maka perumusan masalah ini untuk mendapatkan pemecahan masalah masalah dengan beberapa pertanyaan di bawah ini.

1. Apakah terdapat pengaruh antara CAR terhadap Return on Asset (ROA) perbankan Syariah Indonesia?

2. Apakah terdapat pengaruh antara NPF terhadap Return on Asset (ROA) perbankan Syariah Indonesia?

3. Apakah terdapat pengaruh antara FDR terhadap Return on Asset (ROA) perbankan Syariah Indonesia?

4. Apakah terdapat pengaruh antara BOPO terhadap Return on Asset (ROA) perbankan Syariah Indonesia?

\section{Tujuan Penelitian}

1. Untuk mengetahui apakah terdapat pengaruh antara CAR terhadap Return on Asset (ROA) perbankan Syariah Indonesia ?

2. Untuk mengetahui apakah terdapat pengaruh antara NPF terhadap Return on Asset (ROA) perbankan Syariah Indonesia?

3. Untuk mengetahui apakah terdapat pengaruh antara FDR terhadap Return on Asset (ROA) perbankan Syariah Indonesia?

4. Untuk mengetahui apakah terdapat pengaruh antara BOPO terhadap Return on Asset (ROA) perbankan Syariah Indonesia?

\section{Tinjauan Pustaka}

1. Literature Review

Menurut Benzing (2009), Banyak faktor yang dapat mempengaruhi tingkat kesuksesan sebuah perusahaan, termasuk di dalamnya adalah perusahaan jasa seperti Bank syariah. Variabel variabel yang berkontribusi terhdap kesuksesan sebuah bisnis diantaranya yaitu 
memiliki mental atau jiwa enterpreneurship, kemampuan manajerial yang baik dan pengaruh dari lingkungan eksternal.

Faktor-faktor yang secara signifikan menjadi pendorong peningkatan kinerja industri perbankan syariah baik dalam kegiatan penghimpunan dana maupun penyaluran pembiayaan baik dalam kegiatan penghimpunan dana maupun penyaluran pembiayaan, menurut Halim (2012), yaitu: Pertama, ekspansi jaringan kantor perbankan syariah mengingat kedekatan kantor dan kemudahan akses menjadi salah satu faktor yang mempengaruhi pilihan nasabah dalam membuka rekening di bank syariah. Kedua, gencarnya program edukasi dan sosialisasi kepada masyarakat mengenai produk dan layanan perbankan syariah semakin meningkatkan kesadaran dan minat masyarakat. Ketiga, upaya peningkatan kualitas layanan (service excellent) perbankan syariah agar dapat disejajarkan dengan layanan perbankan konvensional. Salah satunya adalah pemanfaatan akses teknologi informasi, seperti layanan Anjungan Tunai Mandiri (ATM), mobile banking maupun internet banking.

Tingkat kesuksesan juga dapat dilihat dari sisi profitabilitasnya, hasil penelitian M. Kabir Hassan and Abdel-Hameed M. Bashir ( 2002), bahwa terdapat beberapa faktor yang mempengaruhi profitabilitas atau kinerja bank syariah, diantaranya yaitu rasio modal berpengaruh positif sedangkan rasio pinjaman berpengaruh negatif terhadap profitabilitas perbankan syariah. Portofolio pinjaman Bank Syariah sangat condong ke arah pembiayaan perdagangan jangka pendek. Dengan demikian, pinjaman mereka berisiko rendah dan hanya berkontribusi sedikit pada keuntungan bank. Selanjutnya harus memperhatikan pendanaan jangka pendek dari nasabah, aset produktif tanpa bunga, dan biaya untuk promosi, fakor perpajakan dan lingkungan ekonomi makro yang kondusif dapat merangsang pertumbuhan keuntungan yang lebih tinggi.

Pada faktor efisiensi biaya operasional atau BOPO, beberapa penelitian mendapatkan hasil bahwa BOPO ini berpengaruh negatif terhadap profitabilitas. Menurut Abdul Wahab dkk (2014), pada model ROA, variabel yang mampu mempengaruhi kinerja 10 BUS terbesar di Indonesia adalah variable FDR dan BOPO. Pengaruh yang diberikan FDR adalah positif signifikan artinya semakin tinggi FDR dari BUS maka semakin tinggi juga kinerja BUS yang diukur oleh ROA. Selain FDR, BOPO merupakan variabel yang mampu mempengaruhi kinerja ROA, pengaruh yang diberikan oleh BOPO adalah negatif. Penelitian lainnya dilakukan oleh Sukarno, K, W and Syaichu M. (2006), dengan hasil bahwa BOPO dan DER memiliki pengaruh negatif terhadap ROA, dan CAR, FDR, dan NPF memiliki pengaruh positif terhadap ROA. hal ini juga sejalan dengan hasil penelitian Sabir, dkk (2012), bahwa Pengaruh Rasio Kesehatan Bank terhadap Kinerja Keuangan Bank Umum Syariah dan Bank Konvensional Di Indonesia. Hasil penelitian menunjukkan bahwa CAR dan NPF tidak berpengaruh signifikan terhadap ROA, BOPO berpengaruh negatif dan signifikan terhadap ROA, NOM dan FDR berpengaruh positif dan signifikan terhadap ROA pada Bank Umum Syariah di Indonesia. Sedangkan CAR dan NIM berpengaruh positif dan signifikan terhadap ROA, BOPO tidak berpengaruh terhadap ROA, NPL dan LDR berpengaruh negatif dan signifikan terhadap ROA pada Bank Konvensional di Indonesia.

Omar dan Ashraf (2012), menunjukkan bahwa bank dengan ukuran aset yang lebih besar dan manajemen dengan efisiensi yang baik dapat mempengaruhi pengembalian aset yang lebih besar, hal ini berarti bahwa efisiensi manajemen mengenai biaya operasional secara signifikan mempengaruhi profitabilitas bank.

Akhtar dkk, (2011), melakukan penelitian pada bank syaraih di Pakistan dengan hasil bahwa manajemen aset berpengaruh positif terhadap profitabilitas bank syariah. Ukuran bank tidak berpengaruh terhadap profitabilitas bank syariah, hal ini karena sebagian besar bank syariah menghadapi kerugian dalam beberapa tahun terakhir. Sedangkan rasio 
kecukupan modal berpengaruh positif karena peraturan dengan prinsip kehati-hatian diperketat oleh bank Negara Pakistan.

Secara teori menurut Anouar Hassoune ( 2002), bank syariah jauh lebih efektif dalam pembagian keuntungan karena menggunakan porsi bagian dengan nasabah, namun hal ini membuat profitabilitas bank syariah lebih tidak stabil. Bank syariah jauh lebih menguntungkan dari pada perbankan konvensional dengan alasan bahwa bank-bank Islam mendapat manfaat dari ketidaksempurnaan pasar, yaitu tersedianya simpanan dalam jumlah besar yang tidak perlu dibayar margin keuntungannnya, tentu hal ini sangat mengurangi biaya pendanaan. namun perbankan syariah juga tetap mengalami kendala dalam hal likuiditas, risiko konsentrasi dan efisiensi operasional dalam upaya meningkatkan profitabilitasnya.

Alper dan Anbar (2011), menguji determinan yang berpengaruh terhadap profitabilitas bank di Turki dengan variabel spesifik bank dan indikator makro ekonomi, bahwa ukuran aset dan pendapatan non-bunga memiliki pengaruh positif dan signifikan terhadap profitabilitas bank. Namun, ukuran portofolio kredit dan pinjaman memiliki dampak negatif dan signifikan terhadap profitabilitas bank. Berkenaan dengan variabel ekonomi makro, hanya tingkat bunga riil yang mempengaruhi kinerja bank secara positif. Hasil ini menunjukkan bahwa bank dapat meningkatkan profitabilitas mereka melalui peningkatan ukuran bank dan pendapatan non-bunga, mengurangi rasio kredit / aset. Selain itu, tingkat bunga riil yang lebih tinggi dapat menyebabkan profitabilitas bank yang lebih tinggi.

\section{E. Hipotesis Penelitian}

Dari latar belakang masalah, rumusan masalah, tujuan penelitian, dan kerangka pemikiran dari penelitian ini maka dapat diajukan hipotesis penelitian sebagai berikut :

1. H1 : CAR berpengaruh positif signifikan terhadap ROA

2. H2 : NPF berpengaruh negatif signifikan terhadap ROA

3. H3 : FDR berpengaruh positif signifikan terhadap ROA

4. H4 : BOPO berpengaruh negatif signifikan terhadap ROA

\section{F. Metodologi}

Jenis penelitian ini merupakan penelitian kuantitatif. Kuantitatif adalah metode penelitian yang menekankan pada pengujian teori teori melalui pengukuran variabelvariabel penelitian dengan angka dan melakukan analisis data dengan prosedur statistik. Data diambil dari tahun 2010 sampai dengan 2017. Objek penelitian ini adalah Bank umum syariah yang sudah beroperasi minimal selama 8 tahun.

Data yang digunakan berupa data sekunder yakni laporan keuangan. Variabel independen yang digunakan dalam penelitian ini didapatkan dari penelitian terdahulu yang telah terbukti mampu menjelaskan pengaruhnya terhadap kinerja bank. Adapun variabel independen tersebut adalah Capital Adequacy Ratio (CAR), Non Performing Financing (NPF), Financing Deposit Ratio (FDR), dan Biaya Operasional terhadap Pendapatan Operasional (BOPO). Sedangkan variabel dependen adalah profitabilitas bank yang diproksikan dalam rasio Return On Assets (ROA).

Kemudian untuk melihat hubungan antar variabel baik dalam silang tempat dan runtut waktu, maka digunakan model regresi panel data. Metode analisis tersebut dapat dirumuskan sebagai berikut:

$$
\begin{aligned}
& \text { Yit }=\beta O+\beta_{1} X_{1 i t}+\beta_{2} X_{2 i t}+\beta_{3} X_{3 i t}+\beta_{4} X_{4 i t}+\varepsilon \\
& \text { Yit = ROA } \\
& \beta=\text { konstanta } \\
& i=\text { nama bank umum } \\
& t=\text { periode waktu } \\
& \varepsilon=\text { error term } \\
& X_{1}=\text { Capital Adequacy ratio (CAR) }
\end{aligned}
$$




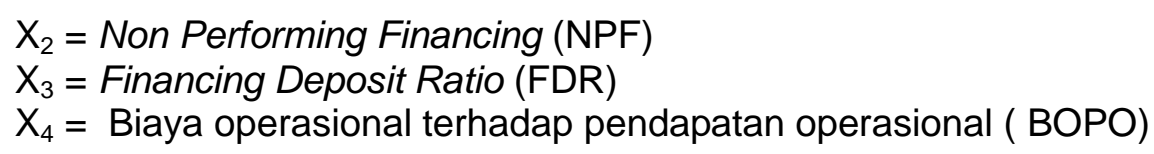

\section{G. Hasil dan Pembahasan}

2. Deskriftif Statistik

Pada tabel 4.1, sudah merangkum semua variabel yang digunakan dalam penelitian ini. Penelitian ini menggunakan jumlah sampel dari perusahaan perbankan yaitu 11 Bank Umum Syariah pada periode 2010-2017 yang telah menyerahkan laporan tahunan secara lengkap dan data laporan tersebut dipublikasikan secara umum.

Tabel 4.1

Desciptive Statistics

\begin{tabular}{|l|c|r|r|r|r|}
\hline & $\mathrm{N}$ & Minimum & Maximum & Mean & Std. Deviation \\
\hline ROA & 88 & $-20,13$ & 6,93 &, 4373 & 3,34227 \\
\hline CAR & 88 & 10,60 & 195,14 & 26,7965 & 26,29478 \\
\hline NPF & 88 &, 00 & 43,99 & 4,5160 & 6,39685 \\
\hline FDR & 88 & 16,98 & 289,20 & 95,1559 & 31,61800 \\
\hline BOPO & 88 & 34,73 & 217,40 & 94,8414 & 26,03134 \\
\hline
\end{tabular}

Berdasarkan tabel di atas dapat dilihat bahwa variabel CAR, FDR dan BOPO memiliki mean lebih besar dari standar deviasi yang diartikan bahwa data variabel tersebut berkelompok atau tidak bervariasi. Sedangkan ROA dan NPF memiliki mean yang lebih kecil dari standar deviasi yang dapat diartikan bahwa data variabel tersebut tidak berkelompok atau bervariasi.

Dalam pengolahan data dengan menggunakan analisis regresi panel, dilakukan beberapa tahapan untuk mencari hubungan antara variabel independen dan dependen. Berdasarkan hasil pengolahan data dengan menggunakan software Stata 10 didapatkan ringkasan seperti pada Tabel 4.2 di bawah ini.

\section{Hasil Analisis Regresi Data Panel}

Berdasarkan pengujian yang telah dilakukan, metode regresi data panel yang sesuai adalah metode PLS.

Tabel 4.2

Hasil Uji Regresi dengan Metode PLS, $\alpha=5 \%$

\begin{tabular}{lllll}
\hline Variabel & Koefisien & $P$ & $t_{\text {hitung }}$ & Keterangan \\
& $\beta$ & value & & \\
\hline Konstanta & 1,90463 & 0,006 & & \\
$(\mathrm{C})$ & & 0,550 & 2,75 & Tidak \\
CAR $\left(X_{1}\right)$ & 0,0045175 & 0,000 & & signifikan \\
NPF $\left(X_{2}\right)$ & - & 0,170 & 0,60 & Signifikan \\
FDR $\left(X_{3}\right)$ & 0,4231099 & 0,042 & - & Tidak \\
BOPO $\left(X_{4}\right)$ & & & 13,74 & Signifikan \\
& 0,0086532 & & & Signifikan \\
& - & & 1,37 & \\
& 0,0048468 & & - & \\
& & & 2,03 & \\
\hline
\end{tabular}




$$
\begin{array}{ll}
\text { R-squared } & 0,7046 \\
\text { F-statistic } & 12,38 \\
\text { Prob (F Statistic) } & 0,0000
\end{array}
$$

Berdasarkan tabel 1.3 didapatkan sebuah persamaan seperti yang terlihat pada persamaan di bawah ini:

$Y=1,9046+0,0045 X_{1 i t}-0,4231 X_{2 i t}+0,0086 X_{3 i t}-0,0048 X_{4 i t}$

Pada persamaan terlihat bahwa nilai konstanta yang dihasilkan adalah sebesar hasil 1,9046 yang diperoleh menunjukan bahwa ketika CAR, NPF, FDR dan BOPO dianggap tetap atau konstan maka terjadi perubahan variabel dependen adalah sebesar 1,9046, yang berarti ROA yang dimiliki oleh Bank Umum Syariah Indonesia akan mengalami kenaikan sebesar 1,9046 satuan.

Berdasarkan hasil uji statistik, variabel CAR tidak berpengaruh secara signifikan terhadap Return on Asset (ROA) pada bank umum syariah di Indonesia. Hal tersebut dapat dilihat dari nilai $p$-value sebesar 0,550 lebih besar dari a atau tingkat kepercayaan sebesar 0,05. Sebagian besar penelitian mengindikasikan bahwa jika CAR naik maka ROA akan naik, atau dengan kata lain berpengaruh signifikan positif, namun hasil penelitian ini berbeda dari penelitian penelitian sebelumnya. Hal ini disebabkan oleh fenomena data laporan keuangan bank syariah pada waktu periode penelitian Capital Adequacy Ratio (CAR) mengalami kenaikan sedangkan Return on Asset (ROA) mengalami penurunan. Hal lainnya bila dilihat dari perhitungan CAR diperoleh dari Modal dibagi ATMR kemudian dikalikan $100 \%$, aktiva yang memiliki bobot risiko diantaranya adalah pembiayaan, fixed asset dan aset aset lainnya. Jika Fixed aset dan aset aset lainnya tidak memberikan kontribusi pendapatan bagi bank syariah, jadi jika kenaikan ATMR karena diakibatkan kenaikan aset pada kelompok ini maka dapat dipahami jika CAR tidak mempengaruhi profitabilitas bank. Penyebab kemungkinan lainnya juga kemungkinan dari masih banyaknya dana yang tidak tersalurkan oleh pihak bank syariah dalam produk pembiayaan sehingga keuntungan tidak maksimal, Variabel Capital Adequacy Ratio (CAR) atau rasio kecukupan modal berfungsi menampung risiko kerugian yang mungkin dihadapi oleh bank syariah, semakin tinggi CAR, maka semakin baik kemampuan bank syariah dalam menanggung risiko dari setiap pembiayaan atau aktiva produktif yang berisiko. Rasio ini penting karena dengan menjaga CAR pada batas aman yaitu minimal $8 \%$. Hal ini dapat diartikan untuk melindungi nasabah dan menjaga stabilitas sistem keuangan secara keseluruhan dan secara bertahap akan disesuaikan dengan kondisi perbankan di Indonesia dan perbankan internasional.

Pada saat ini posisi rata rata CAR Bank Umum Syariah sudah sesuai dengan acuan pemerintah, namun ternyata kondisi laba beberapa bank syariah tidak meningkat bahkan menurun. Pihak manajemen bank sangat perlu untuk memperhatikan besarnya CAR yang ideal, jangan terlalu tinggi karena akan meningkatkan dana yang idle dan juga jangan terlalu rendah karena akan dapat menyebabkan permasalahan bagi bank antara lain bank akan kehilangan kepercayaan dari masyarakat, sehingga dana pihak ketiga bank sangat dimungkinkan akan mengalami penurunan yang drastis. Tingkat CAR sangat mempengaruhi kepercayaan masyarakat terhadap bank, dimana kepercayaan masyarakat merupakan modal dasar bagi kelangsungan lembaga keuangan ini. Tingkat CAR yang ideal akan sangat menguntungkan bagi bank dan dapat meningkatkan kepercayaan masyarakat sebagai pemilik dana, sehingga masyarakat akan memiliki keinginan yang lebih untuk menyimpan dananya di bank.

NPF memiliki pengaruh yang signifikan dan memiliki arah yang negatif dengan $R O A$ dengan tingkat probabilitas sebesar 0,000 atau dapat dikatakan dibawah signifikansi level 0,05 . Dengan tingkat koefisien $-0,4321$, menunjukkan bahwa ada pengaruh negatif antara non performing financing (NPF) dengan ROA perbankan Syariah Indonesia, yang berarti 
bahwa Apabila variabel NPF turun atau rendah, ROA perbankan syariah akan mengalami kenaikan, dan begitu pula sebaliknya, bila NPF naik maka ROA akan turun. NPL atau Risiko pembiayaan dalam dunia perbankan biasanya timbul karena kegagalan debitur untuk memenuhi kewajibannya. Komponen - komponennya antara lain yaitu peluang gagal bayar (probability of default) dimana debitur tidak mampu memenuhi kewajibannya kepada bank, tingkat pemulihan (recovery rate) yaitu proporsi klaim atau tuntutan berkaitan dengan upaya pemulihan kinerja bank dan eksposur pembiayaan/kredit yaitu berkaitan dengan jumlah potensi kerugian bila debitur gagal bayar.

Faktor yang menyebabkan variabel NPF berpengaruh secara signifikan pada periode penelitian dikarenakan oleh adanya regulasi dari Bank Indonesia yang mewajibkan agar masing-masing bank mampu menekan tingkat NPF-nya hingga berada pada angka di bawah 5\%. Kondisi Bank syariah saat ini, npf nya cenderung tinggi sedangkan labanya rendah Selain itu, dengan didukung oleh evaluasi dan restrukturisasi dalam manajemen persetujuan pemberian pembiayaan yang semakin berkualitas, seperti produktivitas latar belakang dan kualitas dari debitur kredit yang sangat diperhatikan bank untuk menginvestasikan dananya, dengan demikian dapat membantu upaya bank dalam meminimalisir persentase dari rasio pembiayaan bermasalah (NPL).

Variabel FDR tidak berpengaruh secara signifikan terhadap Return on Asset (ROA) pada bank umum syariah di Indonesia. Hal tersebut dapat dilihat dari nilai p-value sebesar 0,170 lebih besar dari $\alpha$ atau tingkat kepercayaan sebesar 0,05 . Hal ini bank memberikan dananya dengan prinsip kehati hatian yang tinggi sehingga likuiditas terjaga agar tidak timbul pembiayaan yang macet dikarenakan penyaluran dana bank ini.

BOPO memiliki pengaruh yang signifikan dan memiliki arah yang negatif dengan $R O A$ dengan tingkat probabilitas sebesar 0,042 atau dapat dikatakan dibawah signifikansi level 0,05 . Dengan tingkat koefisien $-0,0048$, menunjukkan bahwa ada pengaruh negatif antara BOPO dengan ROA perbankan Syariah Indonesia. Faktor yang menyebabkan variabel BOPO memiliki koefisien negatif dan berpengaruh secara signifikan terhadap ROA perbankan syariah adalah cerminan dari tingginya rasio BOPO pada periode penelitian yang menjelaskan bahwa tingginya rasio tersebut merupakan upaya bank umum syariah dalam meningkatkan efektivitas dan efisiensi bank umum pada masa mendatang dan masa berjalan. Apabila manajemen perbankan syariah dapat melakukan efisiensi pad BOPO maka ROA akan meningkat.

Hasil pengujian BOPO pada penelitian ini sejalan dengan penelitian Kartika dan Syaichu (2006), Omar (2012), M. Kabir hasan (2002), menyatakan dalam perbankan dan industri pada umumnya terjadi hubungan negatif antara biaya operasional dan pendapatan operasional (BOPO) dengan profitabilitas. BOPO menunjukkan seberapa besar bank dapat menekan biaya operasionalnya di satu pihak, dan seberapa besar kemampuan untuk meningkatkan pendapatan operasional di pihak lain. BOPO memiliki pengaruh terhadap kinerja perbankan karena menunjukkan seberapa besar bank dapat melakukan efisiensi terhadap biaya operasional yang dikeluarkan. Semakin kecil rasio BOPO, berarti semakin efisien biaya operasional yang dikeluarkan bank yang bersangkutan sehingga kemungkinan yang lebih besar bagi bank untuk mendapatkan keuntungan yang lebih dan menunjukkan bahwa bank tidak berada dalam kondisi bermasalah.

Dalam analisis lebih lanjut mengenai efek individu, khususnya terkait dengan variabel yang paling dominan mempengaruhi ROA bank umum syariahdi Indonesia, memberikan suatu penjelasan bahwa rasio NPF merupakan variabel yang paling dominan berpengaruh terhadap ROA bank umum syariah di Indonesia. Hasil tersebut diperoleh dari hasil estimasi standardized coefficient beta dengan standar koefisien sebesar -0.4321 (negatif) yang dimilki oleh NPF. Dengan standar koefisien beta sebesar -0.4321 (negatif) yang dimilki oleh NPF maka dapat dijelaskan bahwa jika NPF naik satu persen, maka menyebabkan 
penurunan ROA bank umum syariah sebesar 0.4321 , atau jika NPF turun satu persen, maka menyebabkan kenaikan ROA bank umum syariah sebesar 0.4321

Penelitian ini secara umum menjelaskan bagaimana kondisi ROA bank umum syariah yang ada di Indonesia. Jika dibandingkan dengan beberapa penelitian terdahulu dapat dijelaskan bahwa fenomena saat ini menunjukan perilaku yang berbeda, khususnya dalam melihat pengaruh beberapa variabel yang tidak signifikan mempengaruhi ROA. Variabelvariabel yang tidak signifikan yaitu variabel CAR dan FDR. Ada beberapa kondisi fundamental yang berbeda dari kondisi sebelumnya, seperti adanya LPS (Lembaga Penjamin Simpanan) yang menjamin resiko perbankan, keadaan kompetisi yang semakin ketat dalam industry perbankan serta perubahan regulasi perbankan yang mengarah pada kebijakan Bassel terbaru. Beberapa keadaan tersebut memberikan sebuah implikasi kebijakan internal perbankan yang reaktif dan berbeda-beda sehingga memberikan pengaruh yang lain terhadap penentuan kredit perbankan. Sebagai contoh, kompetisi yang sangat ketat menyebabkan tidak diindahkannya warning NPL yang tinggi. hal ini dapat disadari karena adanya LPS dan asumsi Too Big Too Fail dalam kebijakan perbankan. Dalam perkembangan industry perbankan yang semakin maju, inovasi keuangan dan keuntungan telah mengarahkan bank untuk mencari keuntungan lain selain kredit (traditional activities) ke transaksi-transaksi lain dalam konteks inovasi dan liberalisasi keuangan. Implikasi inilah yang tentunya memberikan sebuah gambaran empiris baru tentang bagaimana gambaran ROA perbankan syariah dipengaruhi oleh risiko risiko karena kondisi perekonomian yang berubah dari waktu ke waktu yang disebabkan karena perubahan lingkungan internal dan eksternal yang terjadi pada nasabah pembiayaan.

\section{H Kesimpulan dan saran \\ 1 Kesimpulan}

Penelitian ini bertujuan untuk mengukur pengaruh variabel internal bank umum (CAR, NPF, FDR dan BOPO) terhadap return on asset (ROA) bank umum syariah di Indonesia periode 2010-2017. Hasil penelitian menunjukkan penetrasi ROA perbankan syariah disebabkan oleh beberapa faktor, antara lain: NPF dan BOPO. Sedangkan CAR dan FDR tidak mempengaruhi ROA.

NPF dan BOPO berpengaruh negatif disebabkan NPF ini muncul dari adanya pembiayaan bermasalah atau kredit macet, semakin kecil nilai NPF maka laba yang diperoleh bank syariah tentu akan meningkat. Sedangkan BOPO merupakan rasio untuk melihat efisiensi yang dilakukan sebuah bank, beban operasional yang tinggi akan memberikan pengurang laba perusahaan.

\section{Saran}

Pada akhirnya kata penulis ingin mengusulkan saran kepada pihak pihak yang dapat mendapatkan manfaat dari penulisan penelitian ini:

1. Perusahaan perbankan dapat mempertimbangan faktor efisiensi (BOPO) dan variabel kredit macet atau NPF karena variabel NPF ini memberikan sumbangsih terbesar yang dapat mempengaruhi kinerja keuangan ROA perbankan syariah sehingga dapat mengambil kebijakan yang tepat terkait pemberian pembiayaan kepada nasabah.

2. Bagi peneliti selanjutnya yang akan membahas mengenai performance bank, agar menggunakan variabel variabel yang lain, termasuk makro ekonomi. 


\section{DAFTAR PUSTAKA}

Akhand Akhtar Hossain, "Bank Sentral dan Kebijakan Moneter di Asia Pasifik", terj Haris Munandar, Jakarta, Pt Raja Grafindo Persada, 2010

D. Nachrowi, Nachrowi dan Hardius Usman. Pendekatan Populer dan Praktis

EKONOMETRIKA Untuk Analisis Ekonomi dan Keuangan. Jakarta: Lembaga Penerbit

Fakultas Universitas Indonesia, 2002.

Dahlan Siamat, "Manajemen Lembaga Keuangan Kebijakan Moneter dan Perbankan", Jakarta, Lembaga Penerbit Fakultas Ekonomi Universitas Indonesia, 2005

Data Statistik Perbankan Indonesia 2017.

Dwi Caesar Nawawi Syahid "Pengaruh faktor eksternal dan internal terhadap kredit bermasalah serta dampaknya terhadap cadangan kerugian penurunan nilai menurut PSAK $55 ”, 2016$

Eduardus Tandelilin, "Portofolio dan investasi Teori dan Aplikasi", edisi 1, Yogyakarta: Kanisius, 2010

Ferry N Idroes, “Manajemen Risiko Perbankan”, Jakarta: Rajawali Press, 2011

Gujarati D.N., "Dasar dasar ekonometrika”, edisi kelima, penerjemah Mangunsong R., Jakarta, Salemba Empat 2013

Ikatan Bankir Indonesia, "Bisnis Kredit Perbankan", Jakarta, PT. Gramedia Pustaka Utama, 2015

Irman Firmansyah, "Determinant of Non performing Loan: The Case of islamic bank in Indonesia" Buletin Ekonomi Moneter dan Perbankan, Volume 17, Nomor 2, Universitas Tasikmalaya, Oktober 2014

Martono, "Bank dan Lembaga Keuangan Lain”, Yogyakarta, Ekonisia, 2010

Muthia Croza Indah, "Pengaruh inflasi, kurs dan tingkat suku bunga terhadap NPL pada bank BTN cabang Padang", Economica; Jurnal of economic and economic education vol 3 no 2 (137-145), 2015.

Peraturan Bank Indonesia Nomor 17/11/PBI/2015

Rivai, Veithzal, "Bank and Financial Institution Management", Jakarta: PT. Raja Grafindo Persada, 2007. 2013

Syofian Siregar, "Statistik Parametrik untuk penelitian Kuantitatif”, Jakarta: Bumi Aksara,

Undang-undang No. 10 tahun 1998 Tentang Perbankan Bab I Pasal 1

Undang-undang No. 21 tahun 2008 Tentang Perbankan Bab I Pasal 1 Ayat 2 